Short communication

\title{
HISTOPATHOLOGICAL EVALUATION OF IN VITRO ICHTHYOPHTHIRIUS MULTIFILIIS CULTURE IN RED KOI (AKA MATSUBA) TISSUE
}

\author{
M. HEIDARIEH ${ }^{1}$, A. A. SHAHBAZFAR ${ }^{2}$, S. MOODI ${ }^{1}$, \\ H. UNGER $^{3} \&$ R. MOHAMMADI MAVALO ${ }^{1}$ \\ ${ }^{1}$ Nuclear Science and Technology Research Institute, Karaj, Iran; ${ }^{2}$ Department of \\ Veterinary Medicine, University of Tabriz, Tabriz, Iran; ${ }^{3}$ Animal Production \\ and Health Laboratory, International Atomic Energy Agency, Vienna, Austria
}

\section{Summary}

Heidarieh, M., A. A. Shahbazfar, S. Moodi, H. Unger \& R. Mohammadi Mavalo, 2016. Histopathological evaluation of in vitro Ichthyophthirius multifiliis culture in Red koi (Aka Matsuba) tissue. Bulg. J. Vet. Med.,19, No 3, 247-251.

In order to develop any effective means of prevention or therapy against Ichthyophthirius multifilis infection, in this project, the in vitro culture of Ichthyophthirius multifilis trophont containing tissue cysts has been developed. This enables researchers to produce antigens and vaccine and to supply pure organisms without any contamination. Healthy Red koi (Aka Matsuba) tail fin and skin were inoculated into tissue culture media, Leibovitz L-15. The trophonts were exposed to tissue culture within $1 \mathrm{hr}$ after removal from the heavily infected Red koi mucus. Twenty-four hours after introduction of trophonts into tissue (skin) culture, most trophonts observed were adjacent to the basement membrane of the epithelial layer of skin. Additionally, higher numbers of mucous cells in the tail fin epithelium were noted $12 \mathrm{~h}$ after trophont introduction into culture. The histological sections of the skin of Red koi (Aka Matsuba) revealed large trophonts of the I. multifiliis after 10 days that were prominently lodged in the epidermal layers. In this research, the ability to culture I. multifiliis opens new opportunities to develop vaccines, test drugs, and clone parasites for genome sequencing.

Key words: fish, histopathological evaluation, Ichthyophthirius multifiliis, tissue culture

The freshwater ciliate Ichthyophthirius multifiliis causes Ich or white spot disease which is recognised to be one of the most pathogenic diseases of wild and cultured freshwater fish, with significant economic losses to aquaculture industry worldwide (Aihua \& Buchmann, 2001). Infections have been reported from all regions where fish are cultured as well as in most continents (Nigrelli et al., 1976). The three stages in life cycle of the parasite are: an infective theront, a parasitic trophont and a reproductive tomont (Maki \& Dickerson, 2003). Mortalities result when large numbers of the mature parasitic trophont stage exit the host causing disruption to 
the epidermis and interfere with the osmotic balance of the host. Current strategies for its treatment and control depend on the use of chemical agents such as formalin, chloramine- $\mathrm{T}$ and a number of disinfectants that include the active agent's hydrogen peroxide and sodium percarbonate to kill waterborne stages of the parasites. Chemotherapy could however hardly control this parasite after penetration into fish skin and gills. The high cost involved in therapy and the public concern for food and environmental safety are other disadvantages of chemotherapy. Thus, vaccination against $I$. multifiliis can be considered as an alternative to chemical treatments and to prevent mortality in fishes (Maki \& Dickerson, 2003). Gamma irradiated (as radiovaccine), formalin inactivated trophont of $I$. multifliis in combination with alginic acid nano particles were used to immunise the rainbow trout. (Heidarieh et al., 2015).

With in vitro culture of organisms it might be possible to produce high quantities of the parasite not only for the purpose of vaccine production but also for other studies, including development of diagnostic tests. Currently fish are used to cultivate the parasite.

There are a number of issues involved in the culture of protozoan parasites, such as I. multifiliis, that make these procedures highly complex and subject to many variables, some of which are known (Nielsen \& Buchmann, 2000; Xu et al., 2002). In vitro culture of organisms at any of these stages within the life cycle involves a tremendous number of variables, including parasite stage, host site, host temperature, host immune responses, parasite species and/or strain, and parasiteprotective mechanisms (Diamond, 1987; Evans, 1987; Visvesvara, 1999). The present study was conducted on adaptation and histopathology evaluation of the $I$. multifiliis to skin culture in vitro.

Fish and parasite (Ichthyophthirius multifilis). Twenty healthy Red koi carps (Aka Matsuba) weighing 4.07 $\pm 0.63 \mathrm{~g}$ from a fish shop in Karaj, Iran were kept in running water (flow rate $1.5 \mathrm{~L} / \mathrm{min}$ ) in polypropylene tanks $(38 \mathrm{~L})$ with water temperature $23 \pm 2{ }^{\circ} \mathrm{C}, \mathrm{pH} 7.8-8$, dissolved oxygen $6.2-8.1 \mathrm{ppm}$, and natural photoperiod (10L:14D).

The parasite, I. multifiliis, was obtained from heavily infected Red koi (Aka Matsuba) caught from a local fish shop. Mature trophonts were collected and transferred to glass aquaria containing aerated tap water at $17-18{ }^{\circ} \mathrm{C}$ until all individuals were heavily infected by the ciliate parasite. After $72 \mathrm{~h}$ the trophonts in infected fish were collected and counted to prepare vials containing 10 trophonts in each vial (Heidarieh et al., 2014).

Tissue preparation. Healthy Red koi (Aka Matsuba) were anaesthetised in MS222 (ethyl-m-aminobenzoate, methanesulfonate salt $80 \mathrm{mg} / \mathrm{L}$ ) and killed by cervical dislocation. Tail fin and skin (from the lateral body wall with sterile instruments into $10.5 \times 7.4 \mathrm{~cm}$ pieces) were cut off and placed in petri dishes with sterile tap water. Then, these were rinsed with Penstrep (100 IU/mL penicillin and $100 \mu \mathrm{g} / \mathrm{mL}$ streptomycin; Gibco) and transferred to fresh sterile tap water $\left(10{ }^{\circ} \mathrm{C}\right)$.

Culture media. Tissue culture was performed using the method of Nielsen \& Buchmann (2000) with some modifications. Prepared tail fin and skin were washed with Hank's balanced salt solution (Sigma) and were inoculated into tissue culture media, Leibovitz L-15 (Gibco) in a fresh tissue culture flask. L-15 culture media was supplemented with $5 \%$ foetal calf serum (FCS), penicillin (100 IU/mL) and streptomycin $(100 \mu \mathrm{g} / \mathrm{mL})$. Cell cul- 
ture flasks were allowed to develop skin and tail fin for 2 to 3 days prior to experiments. Live trophonts (20-25 trophonts per tissue culture flask, $25 \mathrm{~cm}^{2}$ ) were incubated at $25^{\circ} \mathrm{C}$. The trophonts were used within $1 \mathrm{~h}$ after removal from the heavily infected Red koi mucus.

Examination of viable theronts and trophonts. The survival and multiplication of theront and trophont in tissue culture were recorded daily for 10 days with an inverse microscope (Labomed TCM-400, America) (magnification 40-100×).

Histological observations. In order to investigate parasite proliferation in tail fin and skin, experimental histopathology study was performed. Tissue culture flasks were emptied of medium by inversion and also aspiration into a solution of bleach. Tissues were fixed by adding $10 \%$ formalin buffer solution for $48 \mathrm{~h}$, dehydrated in alcohols and cleared xylene and then embedded in paraffin. Sectioning at a 4-5 $\mu \mathrm{m}$ was done on a rotary rocker microtome, then rehydrated in alcohols and stained with haematoxylin-eosin.
At first, multiplication of organisms was determined by inverse microscopic observation of living cultures. Twentyfour hours after parasite introduction into cultures, most trophonts observed were adjacent to the basement membrane of the epithelial layer of skin (Fig. 1). Additionally, light microscopy of fish tail fin revealed normal appearance (Fig. 2), but higher numbers of mucous cells in the tail fin epithelium were noted $12 \mathrm{~h}$ after trophont introduction into culture media. The histological sections of the skin of Red koi (Aka Matsuba) revealed large trophonts of the I. multifiliis that were prominently lodged in the epidermal layers after 10 days (Fig. 3). In vitro culture of organisms at any one of these stages within the life cycle involves a tremendous number of variables, including parasite stage, host site, host temperature, host immune responses, parasite species and/or strain, and parasite-protective mechanisms (Diamond, 1987; Evans, 1987; Visvesvara, 1999). At the present time, there are advantages in the in vitro culture of protozoan parasites;

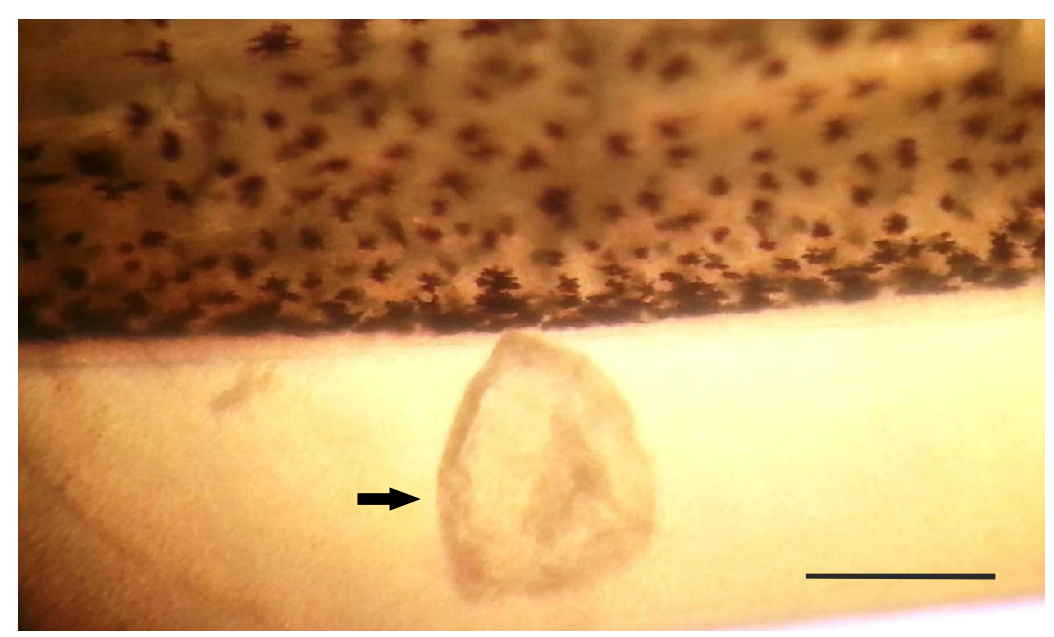

Fig. 1. Trophonts adjacent to the basement membrane of the epithelial layer of fish skin culture after $24 \mathrm{~h}$ (light microscope, bar= $40 \mu \mathrm{m}$ ). 


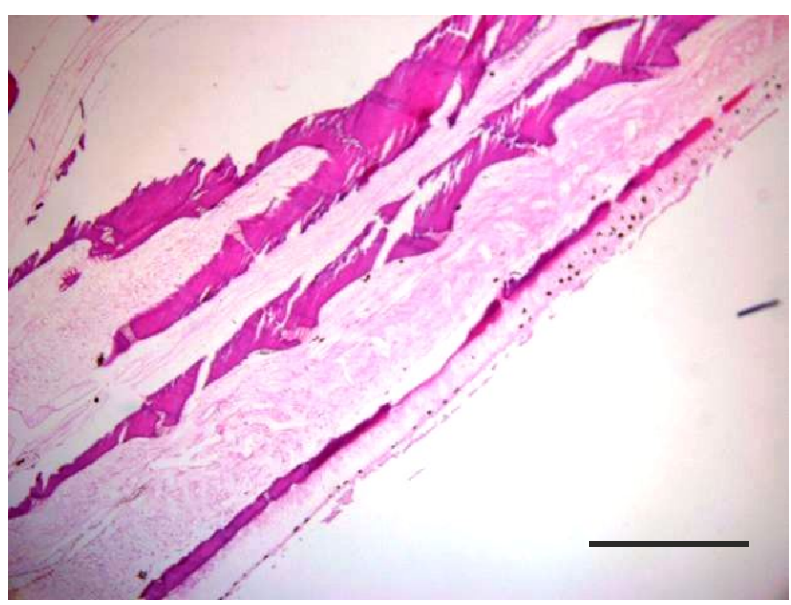

Fig. 2. Fish tail fin culture without any damages (H \& E, bar=200 $\mu \mathrm{m})$.
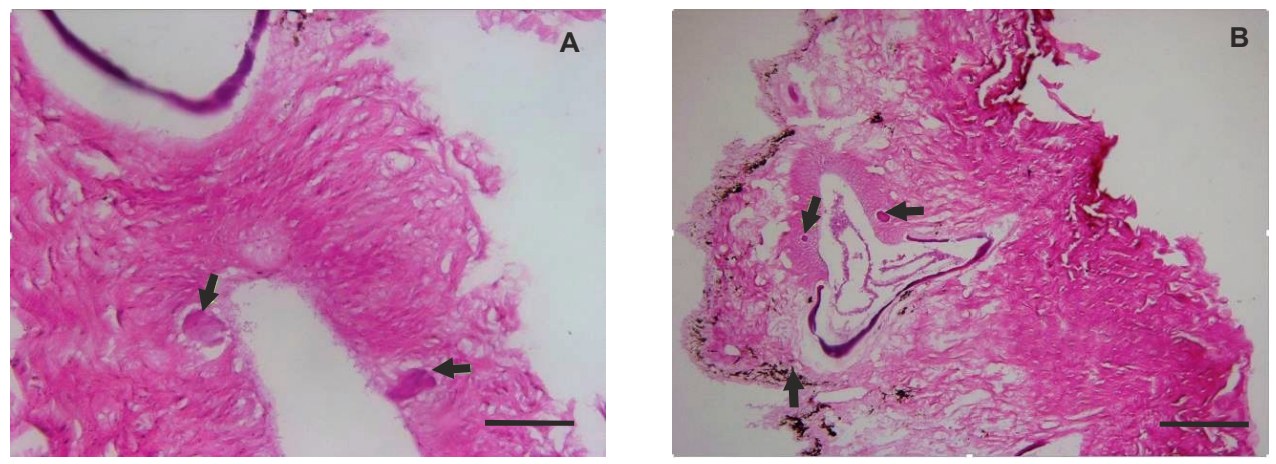

Fig. 3. Parasites appearing in fish skin culture (arrows) after 10 days. $\mathrm{H} \& \mathrm{E}$, bar=200 $\mu \mathrm{m}$ (Fig. 3A); bar=100 $\mu \mathrm{m}$ (Fig. 3B).

one of the great advantages of in vitro culture is that obtaining a continuous supply of pure organisms without any contamination is possible (Trager \& Jensen, 1976; Evans et al., 1999). Also, in vitro cultivation is important for producing antigens, assessing functional antibodies and cell-mediated protective systems against the parasites, screening drugs, identifying potential therapeutic agents and producing vaccines, as relatively large numbers of parasites at specific stages can be produced in culture.
In summary, results demonstrated current culture conditions suitable for I. $\mathrm{mul}$ tifiliis generation in vitro. We hope this in vitro method will provide a basic research tool for understanding of parasite biochemistry, immunology, biology, physiology and for finding suitable drugs for treatment.

\section{ACKNOWLEDGMENTS}

This paper presents results from the FAO/ IAEA Coordinated Research Project (IAEACRP No.16179/R0). The authors are grateful 
for the financial support provided by International Atomic Energy Agency (IAEA), Austria, Vienna and Nuclear Science and Technology Research Institute, Karaj, Iran.

\section{REFERENCES}

Aihua, L. \& K. Buchmann, 2001. Temperature- and salinity-dependent development of a Nordic strain of Ichthyophthirius multiphilis from rainbow trout. Journal of Applied Ichthyology, 17, 273-276.

Diamond, L. S., 1987. Entamoeba, Giardia and Trichomonas. In: In Vitro Methods for Parasite Cultivation, eds A. E. R. Taylor \& J. R. Baker, Academic Press, Orlando, pp. 1-28.

Evans, D. A., 1987. Leishmania, In: In Vitro Methods for Parasite Cultivation, eds A. E. R. Taylor \& J. R. Baker, Academic Press, Orlando, pp. 52-75.

Evans, R., J. M. Chatterton, D. Ashburn, A. W. Joss \& D. O. Ho-Yen, 1999. Cellculture system for continuous production of Toxoplasma gondii tachyzoites. European Journal of Clinical Microbiology \& Infectious Diseases, 18, 879-884.

Heidarieh, M., M. Hedayati Rad, A. R. Mirvaghefi, A. Diallo, Sh. Mousavi, N. Sheikhzadeh \& A. A. Shahbazfar, 2014. Effect of gamma-irradiation on inactivation of Ichthyophthirius multifiliis trophonts and its efficacy on host response in experimentally immunized rainbow trout (Oncorhynchus mykiss). Turkish Journal of Veterinary and Animal Sciences, 38, 388-393.

Heidarieh, M., A. Diallo, S. Moodi, V. Taghinejad, M. Akbari \& A. Monfaredan, 2015. Gene expression analysis in rainbow trout (Oncorhynchus mykiss) skin: Immunological responses to radiovaccine against Ichthyophthirius multifilii. Révue de Médecine Vétérinaire, 166, 233-242.

Maki, J. L. \& H. W. Dickerson, 2003. Systemic and cutaneous mucus antibody responses of channel catfish immunized against the protozoan parasite Ichthyo- phthirius multifiliis. Clinical and Diagnostic Laboratory Immunology, 10, 876-881.

Nielsen, C. V. \& K. Buchmann, 2000. Prolonged in vitro cultivation of Ichthyophthirius multifiliis using an EPC cell line as substrate. Diseases of Aquatic Organisms, 42, 215-219.

Nigrelli, R. F., K. S. Pokorny \& G. D. Ruggieri, 1976. Notes on Ichthyophthirius multifiliis, a ciliate parasitic on fresh-water fishes, with some remarks on possible physiological races and species. Transactions of the American Microscopical Society Journal, 95, 607-613.

Trager, W. \& J. Jensen, 1976. Human malaria parasites in continuous culture. Science, 193, 673-675.

Visvesvara, G. S., 1999. Pathogenic and opportunistic free-living amoebae, In: $M a-$ nual of Clinical Microbiology, $7^{\text {th }}$ edn, eds P. R. Murray, E. J. Baron, M. A. Pfaller, F. C. Tenover, \& R. H. Yolken, ASM Press, Washington, DC, pp. 1383-1390.

Xu, D., P. H. Klesius, C. A. Shoemaker \& J. J. Evans, 2002. The early development of Ichthyophthirius multifiliis in channel catfish in vitro. Journal of Aquatic Animal Health, 12, 290-296.

Paper received 22.06.2015; accepted for publication 25.09.2015

\section{Correspondence:}

Marzieh Heidarieh

Nuclear Science \& Technology Research Institute (NSTRI) PO Box 31485-498, Karaj, Iran e-mail: mheidarieh@nrcam.org 